UDC 339.727.22/24(476)

JEL Classification: E22, F21, G11, 031, Q55

http://doi.org/10.21272/mmi.2018.4-29

Olena Hrechyshkina,

Ph.D., Associate Professor, Polessky State University, Republic of Belarus

Maryia Samakhavets,

Ph.D., Associate Professor, Polessky State University, Republic of Belarus

\title{
IMPORTANCE OF FOREIGN DIRECT INVESTMENT IN FINANCING FOR INNOVATIVE DEVELOPMENT OF THE REPUBLIC OF BELARUS
}

Abstract. The 21st-century trend is the acceleration of scientific and technical progress in conditions of the amplifying competition between producers for free market niches and between countries for leadership. The ideal development model of the modern state is the economy based on knowledge and innovations. At the same time the human potential and other factors of competitive advantages, new technologies are actively involved in this economy. So, conditions for economic growth and life quality improvement are created. Innovative development demands an adequate financial base. Insufficient financing will cause difficulties in the realization of ideas which connected with the introduction of innovative technologies, the release of hi-tech production, the realization of scientific and technical state capacity. Finally, it may lead to technological lag against the increasing level of knowledge intensity in the word. Therefore, the problem of search for adequate innovative development financing becomes important both from the point of view of theoretical judgment and in practice. The purpose of the article is the identification of the place, role and value of the direct foreign investment of innovative development financing of the Republic of Belarus. The carriedout analysis has shown that foreign direct investments inflows differ in considerable fluctuations from year to year. Debt tools prevail in foreign direct investments inflows structure and the investment climate of the Republic of Belarus needs improvement. Dynamic of foreign direct investment inflows are presented in branch and regional section. It is offered to concentrate efforts on foreign direct investments attraction to the hi-tech sector development which is based on V and VI technological modes. It will allow not only to improve investment potential of Belarus but to carry out structural economic transformation on the innovative way. Authors connect further research prospects with studying how to activate scientific and technical international cooperation of the Republic of Belarus with foreign countries. The main interest is cooperation with leading countries in technological development to find out the opportunities of successful experience application in the organization of innovative development financing of the Republic of Belarus, including foreign direct investment inflows.

Keywords: innovative development, innovative activity, financing, foreign investment, foreign direct investment, investment climate, technological mode.

Introduction. One of the world economic trends of the 21 st century is the acceleration of scientific and technological progress alongside the growing competition for free niches in the high-tech products market. Technological leadership is founded on the introduction of innovative technologies, which are based primarily on human potential development and efficiently using new knowledge and information.

We join opinion that it is necessary to pay «close attention to elaboration of new approaches in economic development, it scientific and technical component which will be define future sustainable development of Belarus constructed on rational inclusion to the world system with division and labour cooperation, production and capital» [1]. Scientists [1; 3] unanimously express that it is also necessary to use so-called "windows of opportunities» which can occupy the countries for intensive hi-tech development on the innovative basis and create advancing, but not catching up development model.

Therefore, a highly efficient post-industrial economy, based on knowledge and innovation, becomes the desired model. «Growth of knowledge intensity of GDP and realization as priority need of the person - the continuity of education on the basis of growth of its knowledge intensity» becomes the feature of the modern economy as experts note [7]. The Republic of Belarus has such important development factors

Cite as: Hrechyshkina, O., \& Samakhavets, M. (2018). Importance of Foreign Direct Investment in Financing for Innovative Development of the Republic of Belarus. Marketing and Management of Innovations, 4, 339-348. http://doi.org/10.21272/mmi.2018.4-29 

the Republic of Belarus

as natural resources, favourable geographic location, human potential, which must be used as competitive advantages against external challenges, risks and opportunities [1, pp. 22-36]. It is difficult not to agree that «at the beginning of the 21 st-century development of science and technology will be not the purpose but means of social and economic development of the countries» [2, p. 25]. Experts [2, p. 22] pay attention that technological ways duration will be reduced in connection with the acceleration of scientific and technical progress, and «the changes that are taking place are more radical than perhaps any changes in history» [10].

Experts agree in opinion that the $\mathrm{V}$ technological mode based on the development of electronics, computer facilities and software dominate in the modern economy but new VI technological mode as key factors will include nanotechnologies and genetic engineering in the future.

It is expected, this will enable to create not only science-intensive products for sale, but also high technologies will be introduced into traditional sectors of the economy to increase their competitiveness. By the available estimates [3, p. 7], only $5,2 \%$ of technologies belong to high technologies, $15,8 \%$ - to new technologies and $79 \%$ to traditional technologies in Belarus. Therefore, it is so important to use the existing high human potential of the republic for the intellectual services development, to create innovative industrial and scientific and technological clusters, to expand the potential of the small innovative business and the IT sphere.

Thus, the main goal of innovative development of the Republic of Belarus is a transition to qualitative balanced growth of a new type effective socially-oriented economy based on the strategic accelerated development of high-tech science-intensive industries. This will become the basis for increasing the country's competitiveness and life quality [2, p.11]. V. Gusakov [1, p. 29] notes that state defined priorities in Research \& Development by granting budgetary funds earlier, but non-state sector and population began to play a noticeable role in filling of scientific and technical activity forecasts nowadays.

At the same time, in our opinion, an important restraining factor of innovative activity is an insufficiency of its financing. It seems that there is a risk of the country's technological gap against ongoing innovations "wave" abroad at present. For example, the indicator of science intensity of GDP of the Republic of Belarus is up to $1 \%$, while worldwide average accounts for $2.2-2.3 \%[3, p .8]$ and the leading countries maintain this figure at 4.5\% [4]. The Global Innovation Index shows that Belarus takes the 86th place among 126 countries [5]. The comparison is against the republic also in such indicators as costs of scientific research and development, the number of researchers per 1 million inhabitants and others.

The share of principally new Belarusian products for the world market is insignificant, and the scientific and technical potential of the Republic of Belarus is not fully involved. We join the opinion that the only possible course for Belarusian economy development is the transition to innovative development [6, pp. 20-21]. The growth of science intensity of GDP and use of human capital [7, p. 120] should become distinctive features in the context of globalization. It is obvious that adequate financing is necessary for the national innovation system development. In our view, it is impossible to solve the task of developing and improving the efficiency of national innovation system functioning (including the formation of a market for scientific and technical products and an enabling environment for innovative activities) without improving the financing of scientific, technical and innovation activities. Meanwhile, fiscal, monetary and investment policies should be established to create favourable economic conditions for stimulating innovative development [8] and to enhance the system of its financing.

Recent research and publications analysis. The theoretical and practical foundations of investment and innovative development received considerable coverage and deep understanding of domestic and foreign research papers. Among domestic scientists are the following: V. Gusakov [1], V. Shimov [3], P. Nikitenko [7], L. Nekhorosheva [9] and others, among foreign scientists are P. Drucker [10], T. Calinescu [11], K. Janasz [12], A. Melane-Lavado, A. Alvarez-Herranz, I. Gonzalez-Gonzalez [13], L. Alfaro \& J. Chauvin [14], R. Fatkhutdinov [2], and others. 
V. Gusakov [1] analyzes solutions of economic and social problems of the Republic of Belarus on the basis of global development tendencies among which there are rapid changes in the scientific and technological sphere. Shimov V. [3] identifies the main problems of the Belarusian economy and perspective transformation model of the national economy's development based on the innovation and faster growth strategy.

P. Nikitenko [7] regards the Research \& Development capacity of GDP increase in the context of the new economic model as an innovative creative strategy for the sustainable vital functions of Belarus in conditions of globalization.

P. Drucker [10] considers that world is changing rapidly, and old paradigms will be replaced by new ones, so we should understand what those changes mean and correspond the new rules if we want to be the success.

R. Fatkhutdinov [2] defends and widely lights the idea that the economy can be developed only on the basis of its competitiveness increase by innovative activity intensification.

T. Calinescu [11, p. 14] points out that innovation is an effective method of competition as enabling the creation of new needs, the inflow of investment resources, reduce the cost, improve the image of the manufacturer's new products and services, enhance the quality of life, etc.

L. Nekhorosheva [9] examines the cluster approach as one of the promising areas of innovative development of the Republic of Belarus. However, insufficient financing and lack of a sound system for attracting investors are problematic factors hindering cluster and innovative development.

Financing innovation-technology enterprises are an important issue since the lack of capital for the implementation of innovative projects can lead to their outflow. Capital inflow becomes possible when potential investors are confident that capital investment will lead to the expected return rate, accepting the risk associated with any economic activity [12, p. 26]. The author considers various financing sources for innovation activity and highlights FDI among foreign sources [12, p. 28].

A. Melane-Lavado, A. Alvarez-Herranz, I. Gonzalez-Gonzalez [13, p. 3587] confirm that, on the one hand, technological supply factors are the dominant factors in the FDI location. On the other hand, FDI generates positive side effects by enhancing innovation, increasing competition and achieving technological improvements.

FDI makes enterprises more suitable for developing sustainability-oriented innovations by satisfying the need for technological potential through skilled personnel, technological information and financial capabilities.

L. Alfaro \& J. Chauvin [14] distinguish 3 types of FDI: horizontal, vertical and complex. Horizontal FDI is associated with the establishment of abroad branch company for customer service in the foreign market.

The cost of this is less than the cost of domestic production and delivery to the end market. In the case of vertical FDI, the established foreign affiliate produces inputs or provides intermediate services associated with the final product. This is a response to differences between countries in production costs or the availability of specific factors and inputs. Complex FDI is due to the increasing sophistication of global production and distribution chains, the positioning of firms may be managed by to both horizontal and vertical motives.

However, the issues of investment in innovation remain insufficiently studied due to the rapid development of financial relations in the innovation sphere. These issues are represented by a few scientific papers or are considered only in the context of innovation development and investments for the economic development of the country.

Consequently, the study main purposes are, firstly, the definition of promising innovative areas in the Republic of Belarus and its financing possibilities; secondly, the identification of the role and importance of foreign direct investments (FDI) in the innovative development of the republic, as well as the opportunities for FDI activation. 
Research results. It is possible to use various financing sources for financing innovative development of the Republic of Belarus, such as:

- budgetary and extrabudgetary sources (including innovative vouchers and grants);

- venture sources (including the creation of joint funds with foreign organizations);

- financial resources of the Eurasian Economic Union, the Union State and other international integration associations;

- funds of international financial organizations (World Bank, EBRD, European Investment Bank);

- foreign investment (including those from international stock markets of the Russian Federation, the EU and China) [15].

At the same time, the search of financial sources for innovative development of the republic is accompanied by various restrictions. For example, it is required to include different investment projects in the state programs for obtaining budget funds; to observe certain conditions for financing; to go through appropriate procedures of issue and placement of securities in case of debt or equity financing [16]. Financial support [17] is also provided at the national level (including credits at preferential rates) on a competitive basis through public programs according to their focus on the implementation of the priority areas of country's socio-economic development. It is planned to make a final transition to the program budgeting of capital investments, where the only channel of concessional lending becomes Development Bank of the Republic of Belarus.

Therefore, it is necessary to diversify the financial sources of innovative development of the Republic of Belarus. Within this framework, investment assumes particular importance, and especially FDI. Attracting FDI to the economy of the Republic of Belarus is one of the priorities in accordance with the Program of socio-economic development of Belarus for 2016-2020 years [17].

FDI is considered as the main factor of economic modernization on a debt-free basis, allowing to raise the technological level of business and to create new jobs. This financing source of innovative development is not only an important additional source of funding, but it is also a good opportunity to accelerate the technological renovation of the material and technical facilities of innovation infrastructure subjects, to introduce new technologies, and to modernize the economy as a whole.

However, it should be taken into account that FDI can also have a negative impact together with a positive impact on the country's economy. In particular, this can result in the accumulation of current account deficit in the balance of payments, in the temporary use of local resources and domestic market, in the export of capital in amounts exceeding inputs investments, in the intensification of social differentiation, etc. Therefore, the state should not only stimulate investment activity but strictly regulate it in order to minimize possible negative effects.

The data of the National Statistical Committee of the Republic of Belarus show that in 2016 the share of employees at enterprises with foreign investments amounted to $9.5 \%$, these enterprises provided $25.1 \%$ of revenue, the share of export and import of goods was $21.3 \%$ and $42.4 \%$, respectively [18].

Nevertheless, the share of FDI inflows in Belarus' GDP in 2016-2017 decreased from 2.95\% (in 2015) to $2.61 \%$ (in 2016) and 2.36\% (in 2017) [19]. The largest share of 6.48\% was observed in 2011 due to the sale of the second part of the Belarusian share in JSC Beltransgaz to JSC Gazprom, mainly.

The inward FDI stocks in the Belarusian economy amounted to 19.8 billion US dollars in current prices in 2017 [19]. In comparison with some European countries, this is a little stock (figure 1). This shows that Belarus does not fully use its investment potential. 
O. Hrechyshkina, M. Samakhavets. Importance of Foreign Direct Investment in Financing for Innovative Development of the Republic of Belarus

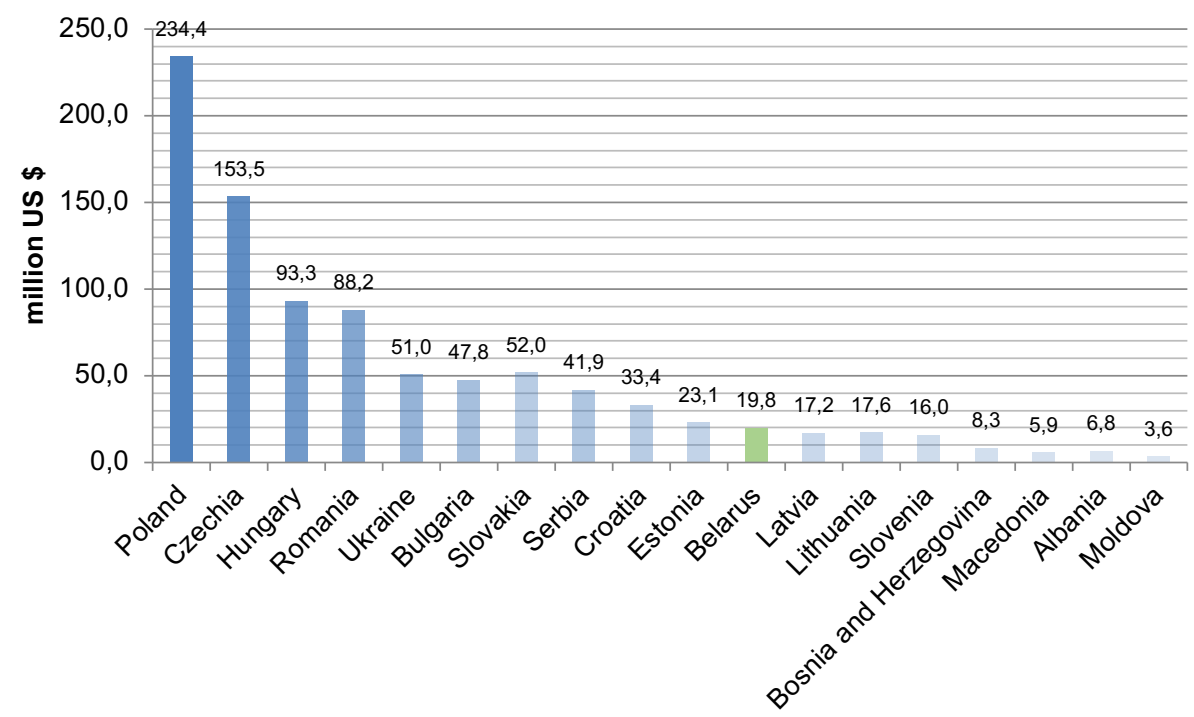

Figure 1 - FDI inward stocks in some European countries

Sources: given according to UNCTAD data [19])

The dynamics of foreign investment inflows in the real sector of the Belarusian economy is presented below (figure 2).

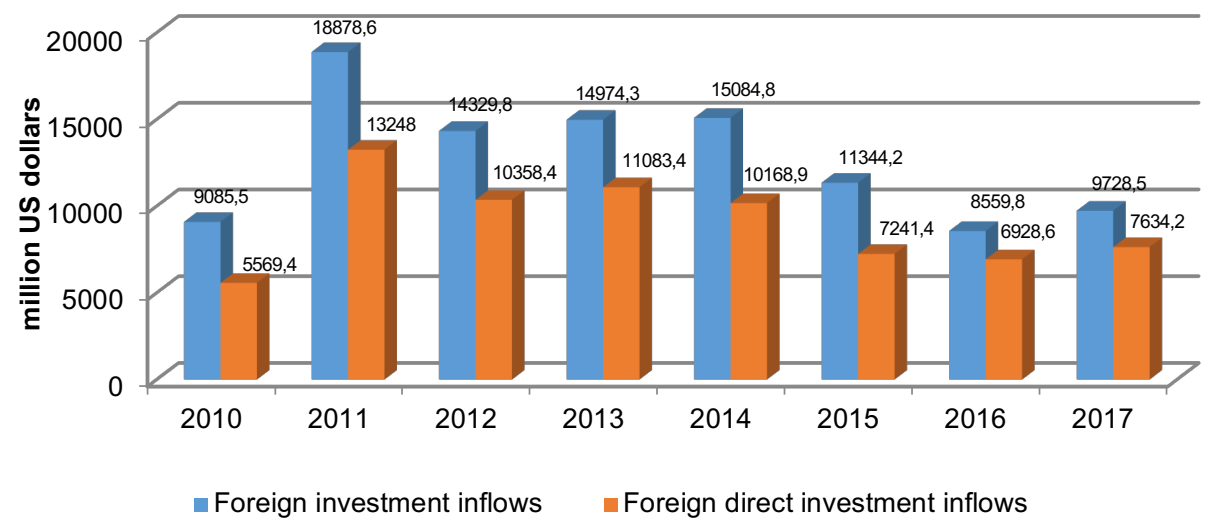

Figure 2 - Dynamics of foreign investment inflows in the real sector of the Belarusian economy

Sources: given according to the National Statistical Committee of the Republic of Belarus data [20])

The largest foreign investment inflows were in 2011 and amounted to 18878.6 million US dollars, including FDI (13248 million US dollars). In 2012 foreign investment inflows dropped by 24.1\%, including FDI by $21.8 \%$. Positive changes were maintained over the next 2 years. Thus, the growth rate of foreign 

the Republic of Belarus

investment inflows in 2013 and 2014 amounted to $4.5 \%$ and $0.74 \%$, respectively. FDI inflows increased by $7 \%$ in 2013 and decreased by $8.25 \%$ in 2014. A significant drop in foreign investment inflows (including FDI) started in 2015 and continued in 2016. In 2017, the situation stabilized, but foreign investment inflows did not reach 2015's level, while FDI inflows exceeded the indicators of 2015 up 392.8 million US dollars. Foreign investment inflow amounted to 9,728.5 million US dollars, including FDI 7634.2 million US dollars in 2017. The structure of foreign investment inflows varied somewhat (table 1) during the analysed period of time. So, if in 2010 the share of FDI inflows was to just over $60 \%$, then in 2017 it increased to $78.5 \%$.

Table 1 - FDI inflows in the Republic of Belarus (structure, \%)

\begin{tabular}{|l|c|c|c|c|c|c|c|c|}
\hline \multicolumn{1}{|c|}{ Indicators } & $\mathbf{2 0 1 0}$ & $\mathbf{2 0 1 1}$ & $\mathbf{2 0 1 2}$ & $\mathbf{2 0 1 3}$ & $\mathbf{2 0 1 4}$ & $\mathbf{2 0 1 5}$ & $\mathbf{2 0 1 6}$ & $\mathbf{2 0 1 7}^{*}$ \\
\hline Foreign investment & 100 & 100 & 100 & 100 & 100 & 100 & 100 & 100 \\
\hline FDI inflows, & 61.30 & 70.17 & 72.29 & 74.02 & 67.41 & 63.83 & 80.94 & 78.47 \\
\hline $\begin{array}{l}\text { including } \\
\text { equities, shares, units }\end{array}$ & 1.92 & 2.21 & 1.97 & 2.15 & 2.35 & 1.72 & 3.40 & \\
\hline reinvestment & - & 4.17 & 6.07 & 11.99 & 9.64 & 11.88 & 15.44 & \\
\hline debt instruments, including & 59.33 & 63.71 & 64.16 & 59.80 & 55.34 & 50.14 & 62.05 & \\
\hline credits and loans & 2.86 & 2.19 & 3.22 & 4.99 & 4.38 & 3.89 & 5.01 & \\
\hline financial leasing & 0.09 & 0.01 & 0.07 & 0.01 & 0.0027 & 0.0003 & - & \\
\hline
\end{tabular}

* Data on the structure of FDI inflows in 2017 on the website of the National Statistical Committee of the Republic of Belarus are not presented.

Sources: National Statistical Committee of the Republic of Belarus data [20; 21]

The share of less than 70\% was observed in 2010, 2014-2015. Debt instruments (62.05\%), which do not affect capital gains and will require a return on capital in the future, are dominant in the structure of FDI inflows. Reinvestment, which represents the turnover of income received mainly in the country of investment, accounts for $15.44 \%$. The share of investments in statutory funds is minimal (3.4\%).

Regional structure of organizations with FDI varies considerably. More of them were concentrated in Minsk (over 53\%) and in Minsk region (over 16\%), and much less (from 5\% to $8 \%$ ) were concentrated in other regions of the Republic of Belarus (on 01/01/2017).

Most of the investment inflows were sent to such fields as transport, postal and courier activities, warehousing $(38.58 \%)$, wholesale and retail trade, car-repairing and motorcycles $(34.93 \%)$, industry $(15.13 \%$, including the processing industry $-14.16 \%$ ), information and communication (5.07\%) according to the FDI inflows structure by economic activity in 2016. The total revenue according to these types of economic activity is $93.71 \%$. Table 2 shows how the structure was changing over the years 2010-2016.

As you can see from table 2, FDI inflows structure has become more differentiated by types of economic activity, but redistribution has occurred mainly in the same types. Trade and transport activities are the most attractive for foreign investors. Changes were minor for other types of economic activity. Insufficient levels of investment are in the manufacturing industry and high-tech industries. The minimum investments (their total proportion is only 1.1\%) were directed in such areas as agriculture, forestry and fisheries, education, health and social services, art, sports, entertainment and leisure, temporary accommodation and food services. Thus, FDI inflows remain a quite narrow specialization and focus on the infrastructure sector (trade, transport, communications), but not in the export-oriented sectors of the economy. This indicates that investors are primarily interested in new markets or in using the purchasing power of the local economy. Therefore, the positive effect of investment for economic development is lower than expected. 
O. Hrechyshkina, M. Samakhavets. Importance of Foreign Direct Investment in Financing for Innovative Development of the Republic of Belarus

Table 2 - Largest FDI inflows by economic activity (share, \%)

\begin{tabular}{|l|c|c|c|c|c|c|c|}
\hline \multicolumn{1}{|c|}{ Type of economic activity } & $\mathbf{2 0 1 0}$ & $\mathbf{2 0 1 1}$ & $\mathbf{2 0 1 2}$ & $\mathbf{2 0 1 3}$ & $\mathbf{2 0 1 4}$ & $\mathbf{2 0 1 5}$ & $\mathbf{2 0 1 6}$ \\
\hline Industry & 5.31 & 6,85 & 9.87 & 11.10 & 12.17 & 11.75 & 15.13 \\
\hline $\begin{array}{l}\text { Wholesale and retail trade; repair of motor vehicles } \\
\text { and motorcycles }\end{array}$ & 13.76 & 44,77 & 47.31 & 41.37 & 37.71 & 45.06 & 34.93 \\
\hline $\begin{array}{l}\text { Transport activities, storage, postal and courier } \\
\text { activities }\end{array}$ & 77.27 & 42,33 & 36.07 & 37.55 & 39.04 & 31.20 & 38.58 \\
\hline Temporary accommodation and food services & 0.32 & 1.86 & 2.62 & 3.31 & 3.90 & 5.02 & 5.07 \\
\hline
\end{tabular}

Sources: National Statistical Committee of the Republic of Belarus data [21]

However, strategic priority and indicator of the development of the Republic of Belarus during the transition to an innovative economy should be increasing high-tech sector (up to 8-10\% of GDP in 2030) based on $\mathrm{V}$ and $\mathrm{VI}$ technological modes in addition to the existing sectors of the economy. This requires the creation and rapid development of high-tech industries with high added value, reducing the energy intensity of production (35\% in 2030) and environmental safety increasing, the development of information and engineering services and transport infrastructure.

Innovative development always starts with finding innovative opportunities and such searching should be organized and conducted on a regular systematic basis [23]. Efforts concentration and funding of priority areas determines the structural economic transformation direction and FDI inflows direction at the same time. Priority areas [24] are information and communication technology and aerospace; additive technology; nuclear energy, and renewable energy sources; bio- and nano-industry; pharmaceutical industry; instrumentation, electronics and robotics; electric transport and its infrastructure.

National Investment and Privatization Agency with the support of the World Bank implements a pilot project "Support for privatization". The main goal is creating an institutional framework for the implementation of the individual and transparent approach to the privatization based on the generally recognized international standards and taking into account Belarusian state interests. Possible methods for the attraction of strategic investors are the following: privatization, joint ventures, acquisition of additional shares [25].

During the Belarusian Investment Forum 2017 in Minsk, it was emphasized that Belarus has advanced investment legislation with various preferential regimes that create economic preconditions for the investors coming to small and medium-sized cities, free economic zones, Chinese-Belarusian Industrial Park "Great stone" and high-tech Park [26]. Quite comfortable conditions for doing business in Belarus are supported by international estimates. Belarus ranks 38th of 190 countries in Doing Business-2018 and belongs to TOP-10 countries by favourable reforms for business [27].

It provides a number of measures for investment activity stimulating by the Program of social and economic development of Belarus in 2016-2020 year [17]. Moreover, Ministry of Industry of the Republic of Belarus offers 13 public companies for the privatization and some investment projects [28] for the implementation. However, net FDI inflows statistics (except direct investor debts for goods, works and services) shows significant fluctuations and steady growth trend absence (figure 3 ). Therefore, the investment policy of the Republic of Belarus is not sufficiently effective despite stimulating measures.

Thus, the Belarusian investment climate remains insufficiently favourable to foreign investors. FDI inflows are sporadic. Experts explain that Belarus is not involved in the global capital market and close the most attractive sectors for investors. In addition, the proposed investment projects often have a low level of profitability. Therefore, investment proposals must contain qualitatively prepared key factors that influence the investor decision-making. These factors (in addition to profitability) should include investments safety guarantee, state support measures, export investment income ability, access to land and property, qualified personnel and others. 
O. Hrechyshkina, M. Samakhavets. Importance of Foreign Direct Investment in Financing for Innovative Development of the Republic of Belarus

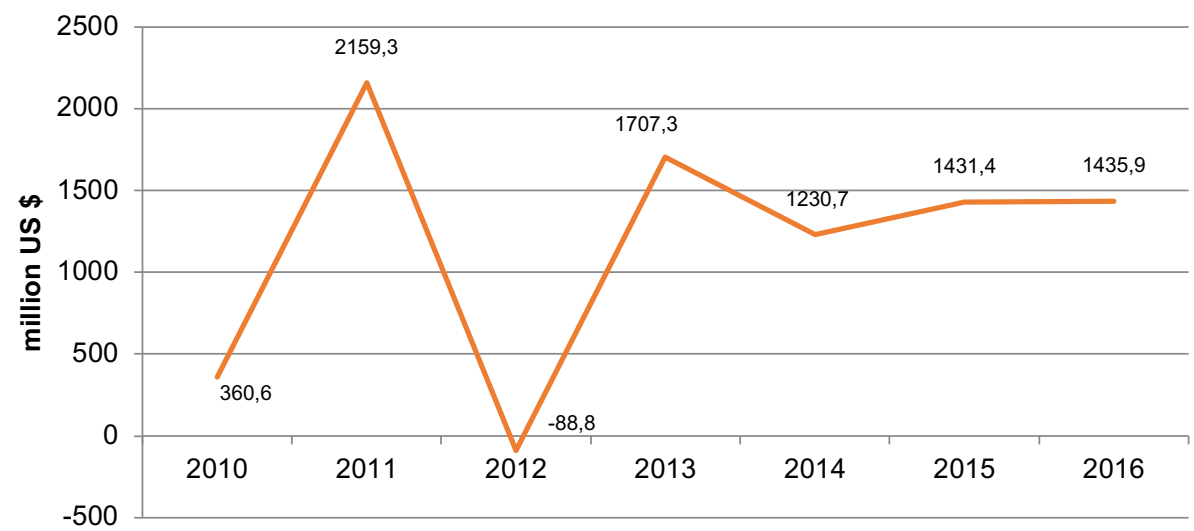

Figure 3-FDI net inflows in the Republic of Belarus

Sources: given according to the National Statistical Committee of the Republic of Belarus data [21]

To our mind the necessary part of investment climate improving are the following activities:

- to focus state organizations on supporting foreign investors, creating favourable conditions, cooperation on the principle of "one window";

- to guarantee foreign investor rights to manage received profit and dividends unconditionally, free capital movement, improvement of international investors security on the basis of international best practices;

- to approximate Belarusian legislation to international best practices with the necessary legal acts' adoption.

It is important to understand the motivation and goals of investors because their influences on the region or even national economy are not always positive. It is necessary to focus on attracting strategic investors exactly to increase the social and economic level and technological development of Belarus. Perhaps, active but not formal measures implementation according to Program of social and economic development of Belarus for 2016-2020 years [17] will improve the investment climate in the Republic of Belarus and will promote more active cooperation with international and regional financial institutions.

Conclusions and prospects for further development. The comprehensive measure implementation for the innovative activities' development, including increasing the FDI inflows role and importance, will lead to the requirements satisfaction for investment resources. These requirements are concentrated in strategically important areas of high-tech industries based on technologies of $\mathrm{V}$ and $\mathrm{VI}$ technological modes in Belarus and help to occupy a niche on the high technology products market. In this case, the main indicator of these measures' success will be increasing the competitiveness of the national economy and providing quality economic growth with improving people's welfare. In conclusion, the prospects for further research are seen in studying the experience of foreign countries-leaders in the high-tech sector. It is interesting to know how foreign countries-leaders in high-tech sector finance innovative development and how to use this successful experience in the Republic of Belarus, as well as prospects for international scientific and technological cooperation development. 
O. Hrechyshkina, M. Samakhavets. Importance of Foreign Direct Investment in Financing for Innovative Development of the Republic of Belarus

\section{References}

1. Gusakov, V.G. (Eds.). (2015). Scientific forecast of economic development of the Republic of Belarus until 2030. Minsk.

2. Fatkhutdinov, R.A. (2012). Innovative management]. (6th ed.). Sankt-Peterburg: Piter

3. Shimov, V. (2014). Development of Belarusian economy: state, problems, the outline of promising information. Belarusian Economic Journal, 2, 4-15.

4. National Strategy for Sustainable Social and Economic Development of the Republic of Belarus for the period until 2030, approved by the Presidium of the Council of Ministers of the Republic of Belarus. (2015). Economic Bulletin of the Institute of the Economy Research Institute of the Ministry of Economy of the Republic of Belarus, 4, 6-97

5. Cornell University, INSEAD, and WIPO. (2018). The Global Innovation Index 2018: Energizing the World with Innovation. Ithaca, Fontainebleau, and Geneva: Cornell University, INSEAD, and WIPO.

6. Miasnikovich, M.V. (2017). Actual agenda for the development of the Belarusian economy in the context of integration. Minsk: Belaruskaia navuka.

7. Nikitenko, P.G. (2014). Model of the new economic mode development is an innovative creative strategy for the sustainable vital functions of Belarus in conditions of globalization. Proceedings of the National Academy of Sciences of Belarus, 1, 119-125

8. Grechishkina, E.A. (2016). Innovations and knowledge: a cluster approach to regional development. Regional innovation cluster: concepts, experience, problems, development prospects. L.E. Sovik, T.V. Bozhidarnik (Ed.). Pinsk : PolesGU.

9. Nekhorosheva, L.N., \& Khostilovich, E. (2015). Kontseptualnye podkhody, metody i instrumenty klasternoi politiki v Respublike Belarus i Polshe: sravnitelnyi analiz [Conceptual approaches, methods and instruments of cluster policies in Belarus and Poland: a comparative analysis]. Belorusskii ekonomicheskii zhurnal - Belarusian Economic Journal, 4, 4-22 [in Russian].

10. Drucker, P.F. (1999). Management challenges for the 21st century. (1st ed.). New York, HarperBusiness.

11. Calinescu, T.V., \& Nedobiega, O.O., \& Natalenko, M.O. (2012). Innovations in the socio-economic development of the region's enterprises. T.V. Calinescu (Ed.); Skhidnoukr. nats. un-t im. Volodymyra Dalia. - Lugansk: SNU im. V. Dalia [in Ukrainian].

12. Janasz, K. (2010). Capital and financing innovation processes in enterprises in Poland: selected aspects. Perspectives of Innovations, Economics and Business, Vol. 1, B. 4, pp. 26-28.

13. Melane-Lavadoa A., Álvarez-Herranza A., González-Gonzálezb I. (2018) Foreign direct investment as a way to guide the innovative process towards sustainability. Journal of cleaner production, Vol. 172, 3578-3590.

14. Alfaro, L., \& Chauvin, J. (2016). Foreign Direct Investment, Finance, and Economic Development. Chapter for the Encyclopedia of International Economics and Global Trade, Forthcoming. Retrieved from: https://ssrn.com/abstract=2908440.

15. Samokhovets, M. P., \& Kravtsova, N. I. (2014). Prospects for Attracting Financial Resources in International Markets by the Republic of Belarus. Studies on Russian Economic Development, Vol. 25, 3, 291-295.

16. Samokhovets, M. P. Rol finansovogo rynka v investitsionnoi politike [Role of the financial market in investment policy] Belorusskii ekonomicheskii zhurnal - Belarusian Economic Journal, 2, $45-56$ [in Russian].

17. Program of social and economic development of the Republic of Belarus for 2016-2020. Retrieved from http://www.government.by/upload/docs/program_ek2016-2020.pdf. [in Russian].

18. Separate statistical indicators of the activities of organizations of the Republic of Belarus, established with the participation of foreign legal entities or individuals for 2016]. (2017). Minsk: Nats. stat. komitet Resp. Belarus

19. Foreign direct investment: Inward and outward flows and stock, annual, 1970-2017. (2018). unctadstat.unctad.org. Retrieved from http://unctadstat.unctad.org/wds/ReportFolders/reportFolders.aspx.

20. The National Statistical Committee of the Republic of Belarus]. (2018). Foreign investments in the Republic of Belarus. Retrieved from http://www.be/stat.gov.by./ofitsialnaya-statistika/makroekonomika-i-okruzhayushchaya-sreda/finansy/godovyedannye_14/inostrannye-investitsii-v-respubliku-belarus/

21. Medvedeva, I.V. (Eds.). (2017). Statistical Yearbook 2017. Minsk: Nats. stat. komitet Resp. Belarus.

22. Utiupin, P. (2017). On the advantages of Belarus for investors, privatization and improving the business climate. Belarus News: Belarusian Telegraph Agency. Retrieved from http://www.belta.by/interview/view/o-preimuschestvah-belarusi-dlja-investorovprivatizatsii-i-uluchshenii-biznes-klimata-5768/

23. Drucker, P.F. (1986). Innovation and Entrepreneurship: Practice and Principles. (1st ed.). New York: HarperCollins Publishers.

24. Ukaz Prezidenta Respubliki Belarus ot 31.01.2017 №31 "O gosudarstvennoi programme innovatsionnogo razvitiia Respubliki Belarus na 2016-2020 gg." s izm. i dop. [Decree of the President of the Republic of Belarus No. 31 "On the State Program of Innovative Development of the Republic of Belarus for 2016-2020" dated 31.01.2017, as amended and supplemented]. Retrieved from http://www.zakon.by/document/?guid=12551\&p0= P31700031\&p1=1 [in Russian].

25. Opportunities for privatization. (2018). Retrieved from http://www.investinbelarus.by/privatization-opportunities/

26. Belarusian Investment Forum in Minsk, September 28-29, 2017. Retrieved from http://www.investinbelarus.by/events/bif/

27. Ease of Doing Business in Belarus. (2018). doingbusiness.org. Retrieved from http://doingbusiness.org/data/exploreeconomies/belarus.

28. Site of the Ministry of Industry of the Republic of Belarus. Retrieved from http://www.minprom.gov.by/privatizacia. 
O. Hrechyshkina, M. Samakhavets. Importance of Foreign Direct Investment in Financing for Innovative Development of the Republic of Belarus

О. О. Гречишкіна, к.е.н., доцент, Поліський державний університет (Республіка Білорусь);

М. П. Самоховець, к.е.н., доцент, Поліський державний університет (Республіка Білорусь)

Роль прямих іноземних інвестицій у фінансування інноваційного розвитку Республіки Білорусь

Прискорення темпів науково-технічного прогресу в умовах посилення конкуренції між виробниками за вільні ніші на ринку та країнами за лідерство стають трендами XXI століття. Ідеальною моделлю розвитку сучасної держави стає економіка, яка базується на знаннях та інноваціях, при умові ефективного виростання людського потенціалу та конкурентних переваг. Так, впровадження нових технологій створює умови для забезпечення економічного зростання та підвищення якості життя населення. Інноваційний розвиток вимагає адекватної фінансової бази, адже недостатнє фінансування буде викликати труднощі в реалізації заходів, пов'язаних із впровадженням інноваційних технологій, випуском високотехнологічної продукції, реалізацією науково-технічного потенціалу держави в цілому, ів кінцевому підсумку призведе до технологічного відставання держави на тлі збільшення рівня наукоємності в світі. Тому завдання пошуку адекватного фінансування інноваційного розвитку стає важливим як з точки зору теоретичного осмислення, так і на практиці. Метою статті $\epsilon$ виявлення місця, ролі та значення прямих іноземних інвестицій у фінансування інноваційного розвитку Республіки Білорусь. Проведений аналіз показав, що надходження прямих іноземних інвестицій відрізняються значними коливаннями за роками, в ї структурі переважають боргові інструменти, а інвестиційний клімат Республіки Білорусь потребуе удосконалення. У статті наведено динаміку надходжень прямих іноземних інвестицій у галузевому та регіональному розрізах. Авторами запропоновано сконцентрувати зусилля із залучення прямих іноземних інвестицій у розвиток високотехнологічного сектора, що базуеться на виробництвах V та VI технологічних укладів. Це дозволить не тільки покращити використання інвестиційного потенціалу Республіки Білорусь, але й здійснити структурну трансформацію економіки на шляху до інноваційного розвитку. Перспективи подальших досліджень автори поєднують з вивченням напрямів активізації міжнародного науково-технічного співробітництва Республіки Білорусь із зарубіжними країнами, в першу чергу країнами-лідерами у технологічному розвитку та можливостями застосування успішного досвіду цих країн в організації фінансування інноваційного розвитку Республіки Білорусь, у т.ч. в рамках залучення прямих іноземних інвестицій.

Ключові слова: інноваційний розвиток, інноваційна діяльність, фінансування, іноземні інвестиції, прямі іноземні інвестиції, інвестиційний клімат, технологічний уклад.

Manuscript received: 16.10 .2018

(C) The author(s) 2018. This article is published with open access at Sumy State University. 